\title{
Towards dynamic flow regime management for floodplain restoration in the Atchafalaya River Basin, Louisiana
}

\author{
Justin P. Kozak ${ }^{1}$, Micah G. Bennett ${ }^{2}$, Bryan P. Piazza ${ }^{3}$, and Jonathan W.F. Remo ${ }^{4}$ \\ ${ }^{1}$ Environmental Resources and Policy Program, Southern Illinois University \\ ${ }^{2}$ Office of Research and Development, U.S. Environmental Protection Agency \\ ${ }^{3}$ The Nature Conservancy, Baton Rouge, Louisiana \\ ${ }^{4}$ Department of Geography and Environmental Resources, Southern Illinois University
}

\begin{abstract}
This study proposes a novel approach for establishing adaptive environmental-flow prescriptions for rivers, channels, and floodways with substantial flow augmentation and a limited decision space using the highly altered Atchafalaya River Basin (ARB) in Louisiana as an example. Development of the ARB into the primary floodway of the Mississippi River and Tributaries Project has contributed to hydrologic changes basin-wide that have altered the riverfloodplain interface threatening important ecosystems, notably the expansive baldcypress-water tupelo swamp forests. Current restoration efforts only address the spatial distribution of water in local areas of the basin; however, the timing, frequency, magnitude, and duration of ecologically-important high and low flows are determined at the basin-wide scale by the daily implementation of a federal flow mandate that limits available water management options. We used current hydrologic conditions and established flow-ecology relationships from the literature to develop an environmental flow prescription for the ARB that provides basin-wide flow targets to complement ongoing restoration efforts. Hydrologic analysis of current flows and the flowecology requirements for these wetland forests revealed an overlap in the range of flow variability under the current water management model, suggesting environmental flows can be complementary with the desired hydraulic and geomorphic characteristics of the floodway. The result is a first step towards an adaptive flow regime that strives to balance important flowecology relationships within a decision space limited by a federal flow mandate. We found high potential for success in managing water for nature while accommodating other management needs for the river.
\end{abstract}

Key words: Environmental flow, water management, flood mitigation, floodplains, wetland forest 


\section{Introduction}

Many river systems around the world have been engineered to produce a select set of ecosystem services which provide substantial economic and social benefits to society (Nilsson et al. 2005). These benefits come with substantial externalities such as altered hydrology, increased nutrient loads, reduced ecological and habitat diversity, and degraded water quality (Sparks 1995; Bunn \& Arthington 2002). Efforts to reduce these externalities include implementing more natural flow regimes and improving floodplain connectivity (Rood et al. 2003; King et al. 2011); however, socioeconomic constraints, existing infrastructure, and a lack of scientific knowledge of watershed-scale process dynamics in large river systems challenges the ability of managers to meet environmental goals (Wohl et al. 2005). Increasing demand for water resources (Vörösmarty et al. 2000) and the uncertain effects of climate change on specific river systems (Palmer et al. 2008) will further challenge current river management approaches.

Restoring a natural flow regime (Poff et al. 1997) is a preferred approach to river restoration, but in many systems, socioeconomic demands and extent of physical alteration preclude the implementation of a natural flow regime. In these cases, environmental flows based on the natural flow regime are prescribed (see: Landres et al 1999; Keane et al 2009).

Environmental flows attempt to restore particular characteristics of the natural flow regime when management options are limited (Acreman \& Dunbar 2004; Arthington 2012). As such, many researchers have advocated for holistic approaches to river restoration where knowledge of the fluvial processes that historically structured target ecosystems is paired with established uses of the river, via the current flow regime, to develop an environmental flow prescription that operates within a socially relevant decision space (Arthington \& Pusey 2003; Poff et al. 2003; Richter et al. 2003; Tharme 2003; Jacobson \& Galat 2008; Acreman et al. 2014).

Improving or reconnecting floodplain flows on regulated rivers is a primary target of river restoration (Opperman et al. 2009; Jacobson et al. 2011; Schindler et al. 2014; Guida et al. 2015). Functioning floodplains are considered among the most valuable, productive ecosystems on Earth (Tockner \& Stanford 2002; Costanza et al. 2014), but their benefits have been historically undervalued or unrecognized (Millennium Ecosystem Assessment 2005; Acreman et al. 2014). Since regulated rivers provide services to society that one can assume will remain in demand, floodplain restoration efforts depend largely on recognizing fundamental changes that have occurred in a river system and identifying a management approach that addresses those changes while meeting existing socioeconomic demands (Holling 2001; Williams et al. 2007; Arthington et al. 2010). Effectively, the decision space for efforts to restore or rehabilitate floodplain wetlands and associated ecosystem services in regulated river systems is delineated by current policies, established socioeconomic uses, and scientific understanding of current and historical hydrological and ecological processes. In many river systems, this scientific understanding will likely need to take place in the absence of a scientific panel or detailed scientific information, such as hydraulic models, due to a lack of resources.

In this paper we develop an adaptive environmental flow prescription for a flow diversion for flood mitigation. The restoration target is floodplain forests in the highly regulated and altered Atchafalaya River Basin (ARB), Louisiana (Figure 1). To do this we work within existing 
management constraints and examine physical and hydrologic changes in the ARB to propose an environmental flow prescription based on a hydrologic analysis and a multi-disciplinary literature review that relates target ecosystem needs to a variety of flow components. The result is an environmental flow prescription that functions within current management constraints to restore, to the extent possible, the basin-wide flow conditions necessary to sustain important habitat and complement existing restoration goals. This is the first attempt we know of to develop adaptive environmental-flow prescriptions for a river or floodway with substantially augmented flows related to flood mitigation and this framework is potentially transferrable to other regulated river systems worldwide.

\section{Study System}

The ARB is the largest contiguous wetland in North America (Ford \& Nyman 2011) and the keystone of a flood mitigation effort that protects large areas of Louisiana from inundation including substantial port infrastructure on the Lower Mississippi River and the city of New Orleans. Its development into a federal floodway and the resulting water management model has altered the physical landscape threatening ecologically important and socially desirable habitat (Piazza 2014).

In 1928, the ARB was designated a principal floodway of the Mississippi River and Tributaries Flood Control Project to be maintained and operated by the U.S. Army Corps of Engineers (USACE). To achieve the desired hydraulic characteristics for flood mitigation, the ARB was significantly modified: basin area was reduced to $26 \%$ of its historic size by flood protection levees (Lambou 1990; Sabo et al. 1999); 22 natural distributaries were cut-off from the main channel; new channels for freshwater distribution were constructed; and the main channel of the Atchafalaya River was leveed for the first $85 \mathrm{~km}$ of its length to contain its flow (Reuss 2004). Also, bank stabilization and river engineering caused a rapid disconnection of swamp habitats from the Atchafalaya River and its distributaries (Piazza 2014).

The increased capacity of the main channel and a more efficient flow path to the Gulf of Mexico contributed to the Atchafalaya River capturing an increasing proportion of Mississippi River flow. To prevent total capture of the Mississippi River by the Atchafalaya River, the Old River Control Structure (ORCS) was completed in 1963 to regulate flow from the Mississippi River into the ARB. The authorizing legislation for ORCS requires that the total annual flow distribution between the Mississippi, Red, and Atchafalaya Rivers be in proportions that occurred in 1950, when $70 \%$ of total flow discharged down the Mississippi and $30 \%$ discharged through the ARB. Because the Red River flows directly into the ARB, the ORCS regulates flow only from the Mississippi River. Flow through ORCS, z, can be conceptualized with the equation:

$$
z=0.3(x+y)-x
$$

where $x$ is the flow in the Red River and $y$ is the flow in the Mississippi River. The result is 6093\% of the flow in the Atchafalaya River comes from the Mississippi River (Mossa 1996), maintaining a flow regime that mimics the Mississippi River and results in seasonal inundation of floodplain forests and riverine wetlands (Piazza et al. 2015). With the exception of flood 
events, USACE policy is to meet this 70/30 flow distribution on a daily basis allowing for a $\pm 7.5 \%$ operational margin (Water in the Basin Committee 2002; Piazza 2014).

The policy of daily adherence to the 70/30 flow distribution limits options for non-flood related water management efforts. The ARB maintains large expanses of floodplain inundation, supports large areas of remote wild lands, high levels of biodiversity, unique habitat (Reuss 2004; Ford \& Nyman 2011; Piazza 2014), and provides market and non-market ecosystem services, including commercial fisheries, recreational hunting and fishing, ecotourism, and high levels of nutrient cycling, valued in the billions of dollars annually (Cardoch \& Day Jr 2001; Atchafalaya Basin Program 2014). Especially important are the baldcypress (Taxodium distichum) - water tupelo (Nyssa aquatica) swamp forests, which are ecologically critically important and also an integral part of the economy and culture of the region.

These swamp forests make up 43\% (106,227 ha) of the Lower Atchafalaya Floodway (Figure 1; Faulkner et al 2009) and support rapid nutrient removal (Groffman et al. 1992; Chambers et al. 2005; Rivera-Monroy et al. 2010) and carbon storage (Watt \& Golladay 1999). They provide critical habitat for many species (Gooding et al 2004; Crook 2008; Ernst \& Lovich 2009), especially for juvenile crawfish, which represent a direct intermediate link in the food web between detritus material and recreationally and commercially important fish species (van Beek et al 1979; Lambou 1990; Bryan et al 1998). When flooded, cypress-tupelo swamps are "hot-spots" for commercial crawfishing, the dominant commercial fishery in the ARB, producing crawfish yields more than 100 times greater than other swamp habitats (Huner \& Barr 1991; Chambers et al. 2005).

Cypress-tupelo swamp productivity and reproduction is determined by the timing, frequency, duration, and spatial distribution of floodplain inundation events, making water stage, rather than discharge, most relevant to forest health. Baldcypress depend on specific hydrological cycles for regeneration (Conner et al. 1986; Kozlowski 1997; Keim et al. 2006) but can survive and grow in nearly permanent inundation, commonly living 400-600 years, with trees found to exceed 1600 years in age (Stahle et al. 1988; Wilhite \& Toliver 1990; Keeland \& Young 1997). Both species can regenerate in damp and frequently inundated soils but seeds will not germinate underwater; total submergence for 4-5 weeks will kill seedlings (Conner \& Buford 1998).

Cypress-tupelo swamps in the ARB are at risk. Faulkner et al. (2009) estimate that only $5.8 \%$ of cypress-tupelo forests in the ARB can regenerate naturally as a result of hydrologic changes, making them a primary focus of restoration efforts (Atchafalaya Basin Program 2014). Current restoration projects in the ARB involve water management in cypress-tupelo swamp forests but only address the spatial distribution of water within Water Management Units distinct hydrologic sub-units of the ARB (U.S. Army Corps of Engineers 2000). These projects aim to prevent flood-induced stress and mortality in cypress-tupelo swamps but are local in scope and constrained by the flow regime at ORCS that ultimately determines the timing, frequency, and duration of flood events. The daily approach to flow regulation may limit largescale restoration alternatives, potentially threatening further loss and degradation of cypresstupelo forests in the ARB (Chambers et al. 2005). 


\section{Data and Methods}

We investigated whether the annual 70/30 flow distribution mandate and the flood mitigation mission can be complementary with the environmental objective of restoring cypresstupelo forests. Then we propose an environmental flow prescription, based on current scientific understanding of the hydrologic needs of cypress-tupelo forests and designed to be implemented within the current flow policy, as a potential way to sustain existing cypress-tupelo forest habitat and associated ecosystem functions and services through large-scale flow management in the ARB (Figure 2).

Specific-gage Analysis

First, we employed specific-gauge analysis (Blench 1969; Biedenharn \& Watson 1997) to track changes in stage over time for a fixed discharge to coarsely assess the effect of altered discharges and river engineering on the carrying capacity of the Atchafalaya River channel. We investigated the stage-discharge relationship along the Atchafalaya River using daily hydrologic data acquired from the USACE (2013) for the period of record for the Simmesport (USGS \#07381490; 1930-present) and Butte LaRose (BLR; USGS \#07381515; 1959-present) gages in the ARB (Figure 1). Simmesport accounts for all flow into the ARB from the Red and Mississippi Rivers and provides discharge data recorded daily at 14:00 Greenwich Mean Time (GMT). There are no other substantial inflows into the ARB. BLR provides stage data recorded daily at 14:00 GMT, is tied to flooding conditions throughout the Lower Atchafalaya Floodway (Allen et al. 2008), and is a benchmark for current restoration efforts. We used the results to determine an appropriate analysis period for this study. We also analyzed the relationship between discharge at Simmesport and stage at BLR to determine if downstream stage heights can be used to set upstream flow targets.

\section{Analysis of the Current Flow Regime}

Then we conducted a one-period analysis of the flow regime at Simmesport from 19882012 using Indicators of Hydrologic Alteration (IHA) software (Richter et al. 1996, 1997; Mathews \& Richter 2007) to identify the current range of flow variability (magnitude, timing, frequency, rate of change, and duration). Given the primacy of flood mitigation to water management in the ARB, any change to the flow regime needs to be compatible with the flood mitigation mission. Used in this way, IHA can help establish boundaries (Range of Variability Approach, see Richter et al. 1998) for the environmental flow prescription that are necessary to maintain desired hydraulic characteristics (i.e., water-surface elevations) within the floodway (Mathews \& Richter 2007). Paired with an understanding of how the carrying capacity of the channel has changed (specific-gage analysis) and the hydrologic needs of cypress-tupelo forests in the ARB (multi-disciplinary literature review), IHA analysis can provide a hydrological basis for individual components of an environmental flow prescription (Richter et al. 2006). The IHA results were used to set boundaries for permissible water infrastructure operations, similar to the sustainability boundary approach proposed by Richter (2010), as a way of translating the sustainability boundary concept (Postel and Richter 2003) into operational targets. In this approach, boundaries are understood to be flexible to accommodate changing social values and 
new scientific understanding of flow-ecology relationships and serve as a basis for consideration of management alternatives (Richter 2010).

\section{Environmental Flow Prescription}

We defined an environmental flow prescription as the future modeled flows required to achieve basin-wide flow conditions necessary to sustain cypress-tupelo forests in the ARB. Generally, the goal was to ensure sufficient water levels in the spring to prevent invasion of hardwoods and provide fish greater access to floodplain habitat and to ensure low water events in summer maximize the productivity and regeneration potential of baldcypress. Flow targets in the environmental flow prescription were based on a review of published literature and reports specific to the ARB that detail important flow regime characteristics for cypress-tupelo forests and associated biogeochemistry and aquatic wildlife (Table 1). These flow regime characteristics were compared with the IHA results to determine if the hydrologic needs of cypress-tupelo habitat are complementary with the current flow policy and the desired hydraulic characteristics of the floodway. Similar to Rood et al. (2003), flow targets were based on optimum stage heights necessary for healthy cypress-tupelo swamps. Here, flow targets were determined using the average discharge of all flow events at Simmesport that produced desired stage at BLR during the study period.

We used flow targets from the literature and IHA analysis of the current flow regime to model flood and dry season flows to serve as a baseline from which modeled flood pulses and flow reductions deviate. To account for interannual variations in flow, we defined each calendar year as either wet (top 25\%), average (middle 50\%), or dry (bottom 25\%) based on mean annual flow (Luce \& Holden 2009). To account for intra-annual variations in flow, we set minimum flows for the flood season -- January 5 to April 15 -- for all years, and defined the flood season as extending to May 15 for average years and to June 1 in wet years. Setting minimum floodseason flows ensures that hydrologic conditions prevent the establishment of bottomland hardwoods and allow cypress-tupelo to remain the dominant forest type (van Beek et al. 1979). Minimum flood-season flows also provide access to important habitat for crawfish and other fishes and allow commercial and recreational fishermen to access favored areas (Water in the Basin Committee 2002; Louisiana Crawfish Promotion and Research Board 2009; Alford \& Walker 2013). We set maximum flows for the dry season, defined as: June 15-October 31 for dry years, June 15-October 15 for average years, and July 1-October 15 for wet years. Maximumallowed dry season flows 1) ensure a majority of cypress-tupelo swamps drain to increase diversity of chemical habitat characteristics; 2) allow accumulated organic debris to oxidize; 3 ) mitigate aquatic invasive species; and 4) support cypress-tupelo forest productivity and regeneration (Bryan et al. 1998; Sabo et al. 1999; Keim et al. 2006, 2006; Faulkner et al. 2009).

Next, we modeled a small flood and a high-flow pulse during wet and average years, respectively, and used IHA results as a guide for magnitude, rise and fall rates, and duration. The time window for this spring pulse is March 15-May 31 to ensure that most annual flooding occurs while temperatures are below the median as part of a strategy to maximize habitat diversity and reduce hypoxia (Sabo et al. 1999). The magnitude of this flood pulse ensures there is good overbank flow to flush hypoxic water and replenish sediment and nutrients in cypress- 
tupelo swamps (Sabo et al. 1999; Water in the Basin Committee 2002; Alford \& Walker 2013). In dry years, intended to coincide with natural climatic droughts, we modeled a flow reduction to maximize natural cypress-tupelo regeneration potential (Bryan et al. 1998; Faulkner et al. 2009). Again, rise and fall rates of flow were held within the current rate of change based on IHA results. These environmental flows were then modeled over the entire study period.

Next, we used the USACE Regime Prescription Tool (HEC-RPT;

http://www.hec.usace.army.mil/software/hec-rpt/) to help visualize the environmental flow prescription for the ARB and to assess performance of the current flow regime in relation to future modeled flows. Flow prescriptions in HEC-RPT are constructed using three types of flow components. Low flows are the foundation of the time series and are defined for each day in a calendar or water year. Pulse flows and flood flows deviate from low flow and are defined by timing, duration, magnitude, and duration of peak flow. Flow prescriptions have one series of low flows but can have multiple pulses and floods. HEC-RPT also tracks differences in flow volume between the imported hydrological record and the environmental flow prescription, especially useful in the ARB where flow volumes are based on a percentage of latitudinal flow.

Because flow prescriptions should be useful from a water management perspective, we produced annual, seasonal, quarterly, and monthly modeled flow volumes. These modeled flow volumes were then used to evaluate the deviation of the flow prescription from recorded flows to assess the feasibility of meeting the environmental objective and the current flow policy (i.e. the 70/30 flow mandate) over time intervals that are more useful for ecosystem management and restoration goals.

\section{Results}

Specific-gage Analysis

Specific-gage analysis revealed 1988-2012 as an acceptable study period because, after a phase of rapid adjustment exhibiting a temporal response pattern similar to the rate law in fluvial geomorphology proposed by Graf (1977), stage at BLR was relatively stable during this time (Figure 3). Further, a strong $\left(\mathrm{R}^{2}=0.98\right)$ relationship between discharge at Simmesport and stage at BLR without any lag adjustment (Appendix A) supports the use of flow targets based on desired stage at BLR. It should be noted that a complex combination of river engineering, levee building, reduced basin extent, and flow modification throughout the ARB is responsible for this change in stage-discharge relationship; however, further hydrologic analysis on this point is beyond the scope of this paper.

\section{Analysis of Current Flow Regime}

IHA analysis revealed mean annual flow (stage at BLR) for the study period (1988-2012) as $6450 \mathrm{~m}^{3} \mathrm{~s}^{-1}(2.8 \mathrm{~m}$ at BLR$)$ with median dates for maximum and minimum flows March $28^{\text {th }}$ and October $22^{\text {nd }}$, respectively. Six wet years $(1991,1993,1998,2008,2009,2011)$ had a mean annual flow of $8000 \mathrm{~m}^{3} \mathrm{~s}^{-1}$ (3.5 m at BLR), and median dates for maximum and minimum flows were May $17^{\text {th }}$ and October $24^{\text {th }}$, respectively. Thirteen average years $(1989,1990,1992,1994-$ $1997,1999,2001-2004,2010)$ had a mean annual flow of $6600 \mathrm{~m}^{3} \mathrm{~s}^{-1}$ (3.0 m at BLR), and 
median dates for maximum and minimum flows were April $15^{\text {th }}$ and October $12^{\text {th }}$, respectively. Six dry years $(1988,2000,2005-2007,2012)$ had a mean annual flow of $4600 \mathrm{~m}^{3} \mathrm{~s}^{-1}(1.9 \mathrm{~m}$ at BLR), and median dates for maximum and minimum flows were February $7^{\text {th }}$ and August $31^{\text {st }}$, respectively (Figure 4).

IHA also identified values for five environmental flow components for the study period (Appendix B), ranging from $935 \mathrm{~m}^{3} \mathrm{~s}^{-1}(0.2 \mathrm{~m}$ at BLR) for extreme low flows to almost 20,000 $\mathrm{m}^{3} \mathrm{~s}^{-1}$ (6.8 $\mathrm{m}$ at BLR) for large floods. Interestingly, IHA classified both established backswamp inundation (6200 $\mathrm{m}^{3} \mathrm{~s}^{-1} ; 2.8 \mathrm{~m}$ at BLR) and overbank flooding $\left(8090 \mathrm{~m}^{3} \mathrm{~s}^{-1} ; 3.7 \mathrm{~m}\right.$ at BLR) thresholds in the lower ARB floodway (Hupp et al. 2008) as low flows based on exceedance probability. The threshold for levee-to-levee flooding $\left(17,300 \mathrm{~m}^{3} \mathrm{~s}^{-1}\right.$; stages above $6.1 \mathrm{~m}$ at BLR; Alford \& Walker 2013) was classified as a small flood, based on exceedance probability.

Small floods typically had the longest duration, and most extreme low-flow events were relatively short in duration (Appendix C). High-flow pulses had a median duration of 22 days and a minimum threshold of $8920 \mathrm{~m}^{3} \mathrm{~s}^{-1}$ and small floods a median duration of 67 days and a minimum peak flow of $13,590 \mathrm{~m}^{3} \mathrm{~s}^{-1}$. The median date for high flows was March 8 and for small floods April 24. Rise and fall rates ranged from approximately $310 \mathrm{~m}^{3} \mathrm{~s}^{-1}$ to $-370 \mathrm{~m}^{3} \mathrm{~s}^{-1}$ for both high-flow pulses and small flood events (Appendix C).

\section{Environmental Flow Prescription}

The hydrologic needs of cypress-tupelo forests in the ARB overlapped with the current range of flow variability, so flow recommendations from the literature were paired with IHA analysis to produce a flow prescription for dry, average, and wet years based on the overlapping hydrologic characteristics (Figure 5; Table 2). The mean annual flows for the modeled wet, average, and dry years were $7120 \mathrm{~m}^{3} \mathrm{~s}^{-1}, 6220 \mathrm{~m}^{3} \mathrm{~s}^{-1}$, and $4920 \mathrm{~m}^{3} \mathrm{~s}^{-1}$, respectively.

\section{Annual}

Seven years met the flow prescription within the $+/-7.5 \%$ operational margin of the $70 / 30$ flow mandate. Over the study period, modeled annual flows ranged from $76-121 \%$ of recorded flows. On average, the environmental flow prescription required $90 \%$ of recorded flows for wet years, $95 \%$ of recorded flows for average years, and $106 \%$ of recorded flows for dry years. Recorded flows for all wet years (6/6) and a majority of average years (8/13) showed higher mean annual flow than modeled, and most dry years (4/6) showed lower mean annual flows than modeled (Table 3).

\section{Seasonal}

When flow volumes for flood and dry seasons were calculated separately, a different picture emerged (Table 3). Recorded flows fluctuated around the minimum flow target in the flood season and the maximum flow target in the dry season. When recorded flows during the flood season were $>100 \%$ of modeled minimum flows, the flow prescription was met and the $70 / 30$ flow distribution was possible for the season. Likewise, when recorded flows during the dry season were $<100 \%$ of modeled maximum flows, the flow prescription was met and the 
70/30 flow distribution was possible for the season. Both conditions were met in 6 years (1988, 1991, 1994, 1999, 2002, 2012), allowing for the current $+/-7.5 \%$ operational margin.

Looking at flood and dry seasons separately, 15 years (60\%) met the minimum requirements of the flow prescription for flood season, meaning the flow prescription was possible within the 70/30 flow mandate and the current operational margin (Table 3). For the dry season, seven years $(28 \%)$ met the maximum flow requirements of the flow prescription for the dry season, meaning less flow occurred that season than the maximum prescribed and the 70/30 flow mandate was achievable.

\section{Quarterly}

Quarterly (calendar year) flow volume calculations revealed further variations in actual and prescribed flows (Table 3). Only four years (16\%; 1991, 1994, 1997, 2002) met the flow mandate and the flow prescription in all four quarters. During January-March, 18 years (72\%) met the requirements of the flow prescription and the 70/30 flow mandate within the operational margin. April-June, which was counted as part of the flood season (minimum required flows), had 15 years $(60 \%)$ meet the requirements of the flow prescription and the 70/30 flow mandate within the operational margin.

The dry season quarter of July-September showed only eight years (32\%) were able to meet the maximum required flows of the flow prescription and the flow mandate within the operational margin. Years that did not meet the flow prescription had 10-56\% more flow than prescribed. October-December begins during the prescribed dry season but ends during the transition period before the flood season. Treated as a dry season period, 19 years $(76 \%)$ met the flow prescription and the 70/30 mandate within the operational margin.

\section{Monthly}

Monthly flow volumes provided a more detailed look at differences between the flow prescription and recorded flows. The flow mandate and flow prescription were met an average of three months per year for dry years, six months for average years, and five months for wet years (Table 4). Only one year (1997) met the flow mandate and prescription for each month during the flood season (January-May) and two years $(1988,2002)$ met the flow mandate and prescription for each month in the dry season (July-October). During the flood season, the flow mandate and prescription were met most often in January and February (68\% of years), March (56\%), and May (60\%). April showed values that met both criteria in only $20 \%$ of years. During the dry season the flow mandate and prescription were met most often in September and October (76\%), followed by August (48\%). July met the flow mandate and prescription only twice (8\%). During the transition period in the flow prescription, recorded flows were evaluated only for adherence to the flow mandate. The mandate was met in only $12 \%$ of years during June and November and $16 \%$ of years during December.

\section{Discussion}

We found that it is possible to manage water for nature, while meeting other management needs for the river. In working rivers, like the Atchafalaya, management constraints often limit 
restoration options more than other constraints like water scarcity or supply. There are a number of examples that show better use of floodwater for riparian and coastal restoration than simply passing floodwaters quickly through floodways and river systems (Sommer et al. 2001; Day et al. 2007). The approach in this study is in line with a functional environmental flows approach (Yarnell et al. 2015), focusing on key processes and habitats to assess environmental objectives within a limited decision-space to achieve beneficial results for nature and people on a highly regulated river. Additionally, this approach to adaptively managing river flows for floodplain reconnection can be applied to river systems that have the necessary infrastructure and existing management constraints (e.g. Illinois River; Red River, Manitoba; Sacramento River: Lower Mississippi River) as well as other flood mitigation efforts that are being considered (e.g. Red River, North Dakota; Dallas Floodway Extension; Middle Mississippi River). By working with the demand for flood protection and other socioeconomic goals, environmental flow prescriptions in these systems become a more viable management option.

The significant anthropogenic alterations on working rivers means restoration efforts are often challenged by current water management models. In the ARB, the altered hydrology has ecological implications that threaten socioeconomic livelihoods in the region through diminished ecosystem service delivery from cypress-tupelo swamp forests. However, hydrologic analysis shows that flow-ecology requirements for these wetland forests overlap with the range of flow variability under the current water management model. This finding suggests environmental flows can be complementary with the desired hydraulic and geomorphic characteristics of the floodway. Further, modeling the environmental flow prescription over different time periods shed light on the ability to meet the federal flow mandate while implementing environmental flows. We had success in meeting both the flow mandate and the flow prescription with quarterly and monthly accounting of flow volumes. A majority of months and quarters had greater than $50 \%$ success rates with late dry-season months and first-quarter success rates greater than $70 \%$. The lack of success for the dry-season quarter (July-September) could pose a water management issue in meeting both the flow mandate and the environmental flow prescription. Overall, deviations from a daily 70/30 implementation would likely be necessary during the dry season, but many years would likely meet the flood-season flow requirements with minimal deviation thereby greatly simplifying flow control management.

Given that the flow mandate is an annual target, from a decision-making perspective, a monthly approach to environmental flows in the ARB appears to have real potential for implementation. The ARB's location at the outlet of a large river basin enables 28-day forecasts for the Lower Mississippi River based on water currently in the watershed and rainfall expected in the next 24 hours (NOAA, n.d.). This ability to forecast reduces decision-making uncertainty in meeting both the flow mandate and environmental flow targets. The 22-day high-flow pulse modeled for average water years can be implemented within forecasted future flows, though the small flood and flow reduction modeled for wet and dry years, respectively, would require a higher level of confidence in expected future flows.

It should be stressed that this approach represents a starting point for adaptively managing environmental flows on highly regulated rivers or floodplains. The premise that 
environmental flows based on the hydrological needs of critical habitat will benefit the ecological functionality and biodiversity of highly regulated river systems is an assumption that requires monitoring and refinement over time. As more knowledge is gained about the impact of the initial flow prescription, whether it meets the needs of the target habitat or what the unintended consequences are, it can be better tailored to meet multiple objectives and balance trade-offs. Further, downstream considerations are needed before any flow alterations on regulated rivers. For the ARB, the Atchafalaya and Wax Lake outlets (Figure 1) are currently the only prograding deltas on the Louisiana coast and play a role in long-term coastal restoration efforts. The impact to sediment delivery and dynamics that could occur with a change in flow distribution at ORCS is also important to the Birds Foot Delta of the Mississippi River, where efforts to reverse coastal erosion and land-loss are ongoing. Such considerations complicate straightforward implementation of environmental flow prescriptions and should be included when developing management alternatives as well as monitoring and adaptive management protocols to assess and limit negative impacts.

When developing environmental flows, there is a need for hydraulic modeling to more accurately estimate inundation extent and patterns and the drying of swamp land. In many rivers, as in the ARB, a realistic hydraulic model (two-dimensional) does not exist because of a lack of validation data and lack of resources. Current estimates in the ARB are based on historic Landsat imagery and only appropriate for use at the basin scale or within specific Water Management Units (Allen et al. 2008). Improved hydraulic modeling, and improved validation using remotely-sense imagery, can further understanding of site-specific inundation patterns (Jung et al. 2012) and flow-ecology relationships facilitating refinement of environmental flow prescriptions.

Finally, a more flexible approach provides water managers the capacity to mitigate environmentally and socioeconomically damaging flow events. For example, in the ARB, since 1996 there have been seven 2-3\% increases in flow through ORCS for 7-16 days during the flood season to increase crawfish production, improve water quality, and protect aquatic resources (Kozak et al., 2015). These management actions are initiated by calls from concerned stakeholders to state agencies, who in turn contact the USACE to request the flow alteration. Such reactionary measures are essentially a stop-gap approach to ecosystem management, are not without cost, and will be further tested in the future when precipitation and drought events are expected to be more variable (IPCC 2007).

\section{Conclusion}

There is a growing need for increased flexibility in water management to aid in the reconnection of riparian wetlands worldwide. The adaptive framework for environmental flows presented here initiates the connection of ecosystem science with water management while accommodating flow management constraints and limited scientific resources. Such an approach to environmental flows provides the opportunity to complement current, small-scale restoration projects with basin-wide flow management and, perhaps more importantly, can provide the necessary framework for the establishment of a more equitable balance between socioeconomic and ecological goods and services. 
Prescribing environmental flows for multi-use, working river systems can be challenging because institutional barriers make it difficult to change how rivers are managed (Wondolleck $\&$ Yaffee 2000). This makes approaches to setting environmental flows that work within an established decision space attractive. Because water demands are expected to increase in the future, a broader implication of this work is that it may be in the best interest of water managers in water-wealthy regions to establish the environment as a legitimate user of water now before the need for environmental flows becomes a more contentious issue. Such a precedent can go a long way toward sustaining local livelihoods dependent on natural and hybrid ecosystems and represents a concerted effort to consider the environment in future water management decisions.

\section{Acknowledgements}

This work was supported by the National Science Foundation (NSF) under Grant No. 0903510. Any opinions, findings, conclusions, or recommendations expressed in this material are those of the authors and do not necessarily reflect the views of the NSF.

\section{Literature Cited}

Acreman, M., A. H. Arthington, M. J. Colloff, C. Couch, N. D. Crossman, F. Dyer, I. Overton, C. A. Pollino, M. J. Stewardson, and W. Young. 2014. Environmental flows for natural, hybrid, and novel riverine ecosystems in a changing world. Frontiers in Ecology and the Environment 12:466-473.

Acreman, M. C., and M. J. Dunbar. 2004. Defining environmental river flow requirements-a review. Hydrology and Earth System Sciences 8:861-876.

Alford, J. B., and M. R. Walker. 2013. Managing the flood pulse for optimal fisheries production in the Atchafalaya River Basin, Louisiana (USA). River Research and Applications. doi: 10.1002/rra.1610

Allen, Y. C., G. C. Constant, and B. R. Couvillion. 2008. Preliminary classification of water areas within the Atchafalaya Basin Floodway System by using Landsat imagery. OpenFile Report 2008-1320. U.S. Geological Survey, Reston, VA.

Arthington, A. H. 2012. Environmental Flows: Saving Rivers in the Third Millennium. University of California Press.

Arthington, A. H., R. J. Naiman, M. E. Mcclain, and C. Nilsson. 2010. Preserving the biodiversity and ecological services of rivers: New challenges and research opportunities. Freshwater Biology 55:1-16.

Arthington, A. H., and B. J. Pusey. 2003. Flow restoration and protection in Australian rivers. River Research and Applications 19:377-395. 
Atchafalaya Basin Program. 2014. Atchafalaya Basin Annual Plan FY 2015. Louisiana Department of Natural Resources.

Biedenharn, D. S., and C. C. Watson. 1997. Stage adjustment in the lower Mississippi River, USA. Regulated Rivers: Research \& Management 13:517-536.

Blench, T. 1969. Mobile-bed fluviology: A regime theory treatment of canals and rivers for engineers and hydrologists. University of Alberta Press, Alberta, Canada.

Bryan, C. F., D. A. Rutherford, L. F. Hale, D. G. Kelly, B. W. Bryan, F. Monzyk, J. Noguera, and G. Constant. 1998. Atchafalaya River Basin hydrological management plan: Research and development. Final Report Contract 512-3019. Federal Emergency Management Agency.

Bunn, S. E., and A. H. Arthington. 2002. Basic principles and ecological consequences of altered flow regimes for aquatic biodiversity. Environmental Management 30:492-507.

Cardoch, L., and J. W. Day Jr. 2001. Energy analysis of nonmarket values of the Mississippi Delta. Environmental Management 28:677-685.

Chambers, J. et al. 2005. Conservation, protection and utilization of Louisiana's Coastal Wetland Forests. Final Report to the Governor of Louisiana from the Coastal Wetland Forest Conservation and Use Science Working Group.

Conner, W. H., and M. A. Buford. 1998. Southern deepwater swamps. Pages 261-287 Southern Forested Wetlands. Lewis Publishers, Boca Raton, Florida.

Conner, W. H., J. R. Toliver, and F. H. Sklar. 1986. Natural regeneration of baldcypress (Taxodium distichum (L.) Rich.) in a Louisiana swamp. Forest Ecology and Management 14:305-317.

Costanza, R. et al. 2014. Change in the global value of ecosystem services. Global Environmental Change 26:152-158.

Cowardin, L. M., V. Carter, F. C. Golet, and E. T. LaRoe. 1979. Classification of wetlands and deepwater habitats of the United States. Fish and Wildlife Service, US Department of the Interior Washington, DC, USA.

Crook, A. 2008. A multi-scale assessment of den selection of Louisiana black bears (Ursus americanus luteolus) in northern and central Louisiana. M.S. thesis. University of Victoria.

Day, J. W. et al. 2007. Restoration of the Mississippi Delta: Lessons from hurricanes Katrina and Rita. Science 315:1679-1684.

Ernst, C. H., and J. E. Lovich. 2009. Turtles of the United States and Canada. JHU Press. 
Faulkner, S. P., P. Bhattarai, Y. Allen, J. Barras, and G. Constant. 2009. Identifying baldcypresswater tupelo regeneration classes in forested wetlands of the Atchafalaya Basin, Louisiana. Wetlands 29:809-817.

Ford, M., and J. Nyman. 2011. Preface: An overview of the Atchafalaya River. Hydrobiologia 658: $1-5$.

Gooding, G., J. R. Langford, and L. K. Ammerman. 2004. Characteristics of tree roosts of Rafinesque's big-eared bat and southeastern bat in northeastern Louisiana. The Southwestern Naturalist 49:61-67.

Graf, W. L. 1977. The rate law in fluvial geomorphology. American Journal of Science 277:178191.

Groffman, P. M., A. J. Gold, and R. C. Simmons. 1992. Nitrate dynamics in riparian forests: Microbial studies. Journal of Environment Quality 21:666.

Guida, R. J., T. L. Swanson, J. W. F. Remo, and T. Kiss. 2015. Strategic floodplain reconnection for the Lower Tisza River, Hungary: Opportunities for flood-height reduction and floodplain-wetland reconnection. Journal of Hydrology 521:274-285.

Holling, C. S. 2001. Understanding the complexity of economic, ecological, and social systems. Ecosystems 4:390-405.

Huner, J. V., and J. E. Barr. 1991. Red Swamp Crawfish: Biology and Exploitation. 3rd edition. Louisiana Sea Grant College Program, Louisiana State University, Baton Rouge, LA.

Hupp, C. R., C. R. Demas, D. E. Kroes, R. H. Day, and T. W. Doyle. 2008. Recent sedimentation patterns within the central Atchafalaya Basin, Louisiana. Wetlands 28:125-140.

IPCC. 2007. Contribution of Working Group I to the Fourth Assessment Report of the Intergovernmental Panel on Climate Change, 2007.

Jacobson, R. B. and D. L. Galat. 2008. Design of a naturalized flow regime - an example fromt eh Lower Missouri River, USA. Ecohydrology 1:81-104.

Jacobson, R. B., T. P. Janke, and J. J. Skold. 2011. Hydrologic and geomorphic considerations in restoration of river-floodplain connectivity in a highly altered river system, Lower Missouri River, USA. Wetlands Ecology and Management 19(4):295-316.

Jung, H. C., M. Jasinski, J.-W. Kim, C. K. Shum, P. Bates, J. Neal, H. Lee, and D. Alsdorf. 2012. Calibration of two-dimensional floodplain modeling in the central Atchafalaya Basin Floodway System using SAR interferometry. Water Resources Research 48. 
Keane, R. E., P. F. Hessburg, P. B. Landres, and F. J. Swanson. 2009. The use of historical range and variability (HRV) in landscape management. Forest Ecology and Management 258:1025-1037.

Keeland, B. D., and P. J. Young. 1997. Long-term growth trends of baldcypress (Taxodium distichum (L.) Rich.) at Caddo Lake, Texas. Wetlands 17:559-566.

Keim, R. F. et al. 2006. Ecological consequences of changing hydrological conditions in wetland forests of coastal Louisiana. In: Xu, Y. J. and Singh, V. P. (eds.), Coastal Environment and Water Quality. Highlands Ranch, Colorado: Water Resources Publications, pp. 383396.

King, A. J., K. A. Ward, P. O’Connor, D. Green, Z. Tonkin, and J. Mahoney. 2010. Adaptive management of an environmental watering event to enhance native fish spawning and recruitment. Freshwater Biology 55:17-31.

Kozak, J. P., M. G. Bennett, A. E. Hayden-Lesmeister, K. A. Fritz, and A. Nickolotsky. 2015. Using flow-ecology relationships to evaluate ecosystem service trade-offs and complementarities in the nation's largest river swamp. Environmental Management55:1327-1342. doi:10.1007/s00267-015-0474-4

Kozlowski, T. 1997. Responses of woody plants to flooding and salinity. Tree Physiology Monograph 1.

Lambou, V. W. 1990. Importance of bottomland hardwood forest zones to fishes and fisheries: The Atchafalaya Basin, a case history. Pages 125-193 Ecological processes and cumulative impacts: Illustrated by bottomland hardwood wetland ecosystems. Lewis Publishers, Chelsea, Michigan, USA.

Landres, P. B., P. Morgan, and F. J. Swanson. 1999. Overview of the use of natural variability concepts in managing ecological systems. Ecological Applications 9:1179-1188.

Louisiana Crawfish Promotion and Research Board. 2009. Wild-Caught Crawfish Management Plan. Louisiana Crawfish Promotion and Research Board.

Luce, C. H., and Z. A. Holden. 2009. Declining annual streamflow distributions in the Pacific Northwest United States, 1948-2006. Geophysical Research Letters 36.

Mathews, R., and B. D. Richter. 2007. Application of the Indicators of Hydrologic Alteration software in environmental flow-setting. Journal of the American Water Resources Association 43:1-14.

Millennium Ecosystem Assessment. 2005. Millennium Ecosystem Assessment: Living Beyond our Means: Natural Assets and Human Well-being (Statement from the Board). Millennium Ecosystem Assessment, India, France, Kenya, UK, USA, Netherlands, Malaysia. 
Mossa, J. 1996. Sediment dynamics in the lowermost Mississippi River. Engineering Geology 45:457-479.

National Oceanic and Atmospheric Administration. (n.d.). Extended Forecast. Available from http://www.srh.noaa.gov/lmrfc/?n=ms_extended_forecast (accessed February 24, 2015).

Nilsson, C., Reidy, C. A., Dynesius, M., and C. Revenga. 2005. Fragmentation and flow regulation in the world's large river systems. Science 308:405-408.

Opperman, J. J., G. E. Galloway, J. Fargione, J. F. Mount, B. D. Richter, and S. Secchi. 2009. Sustainable floodplains through large-scale reconnection to rivers. Science 326:14871488.

Palmer, M. A., C. A. Reidy Liermann, C. Nilsson, M. Flörke, J. Alcamo, P. S. Lake, and N. Bond. 2008. Climate change and the world's river basins: Anticipating management options. Frontiers in Ecology and the Environment 6:81-89.

Piazza, B. P. 2014. The Atchafalaya River Basin: History and Ecology of an American Wetland. Texas A\&M University Press, College Station, TX.

Piazza, B. P., Y. C. Allen, R. Martin, J. F. Bergan, K. King, and R. Jacob. 2015. Floodplain conservation in the Mississippi River Valley: Combining spatial analysis, landowner outreach, and market assessment to enhance land protection for the Atchafalaya River Basin, Louisiana, U.S.A. Restoration Ecology 23:65-74.

Poff, N. L., J. D. Allan, M. B. Bain, J. R. Karr, K. L. Prestegaard, B. D. Richter, R. E. Sparks, and J. C. Stromberg. 1997. The natural flow regime. BioScience 47:769-784.

Poff, N. L., J. D. Allan, M. A. Palmer, D. D. Hart, B. D. Richter, A. H. Arthington, K. H. Rogers, J. L. Meyer, and J. A. Stanford. 2003. River flows and water wars: Emerging science for environmental decision making. Frontiers in Ecology and the Environment 1:298-306.

Postel, S., and B. Richter. 2003. Rivers for Life: Managing Water for People and Nature. Island Press, Washington D.C.

Reuss, M. 2004. Designing the Bayous: The Control of Water in the Atchafalaya Basin, 18001995. Texas A\&M University Press, College Station, TX.

Richter, B., J. Baumgartner, R. Wigington, and D. Braun. 1997. How much water does a river need? Freshwater Biology 37:231-249.

Richter, B. D. 2010. Re-thinking environmental flows: From allocations and reserves to sustainability boundaries. River Research and Applications 26:1052-1063. 
Richter, B. D., J. V. Baumgartner, D. P. Braun, and J. Powell. 1998. A spatial assessment of hydrologic alteration within a river network. Regulated Rivers: Research \& Management 14:329-340.

Richter, B. D., J. V. Baumgartner, J. Powell, and D. P. Braun. 1996. A method for assessing hydrologic alteration within ecosystems. Conservation Biology 10:1163-1174.

Richter, B. D., R. Mathews, D. L. Harrison, and R. Wigington. 2003. Ecologically sustainable water management: Managing river flows for ecological integrity. Ecological Applications 13:206-224.

Richter B. D., A. T. Warner, J. L. Meyer, and K. Lutz. 2006. A collaborative and adaptive process for developing environmental flow recommendations. River Research and Applications 22:297-318.

Rivera-Monroy, V. H., P. Lenaker, R. R. Twilley, R. D. Delaune, C. W. Lindau, W. Nuttle, Habib, E., R. W. Fulweiler, and E. Castaņeda-Moya. 2010. Denitrification in coastal Louisiana: A spatial assessment and research needs. Journal of Sea Research 63:157172.

Rood, S. B., C. R. Gourley, E. M. Ammon, L. G. Heki, J. R. Klotz, M. L. Morrison, D. Mosley, G. G. Scoppettone, S. Swanson, and P. L. Wagner. 2003. Flows for floodplain forests: A successful riparian restoration. BioScience 53:647-656.

Sabo, M. J., C. F. Bryan, W. E. Kelso, and D. A. Rutherford. 1999. Hydrology and aquatic habitat characteristics of a riverine swamp: II. Hydrology and the occurrence of chronic hypoxia. Regulated Rivers: Research \& Management 15:525-544.

Schindler, S. et al. 2014. Multifunctionality of floodplain landscapes: relating management options to ecosystem services. Landscape Ecology 29:229-244.

Sommer, T., B. Harrell, M. Nobriga, R. Brown, P. Moyle, W. Kimmerer, and L. Schemel. 2001. California's Yolo Bypass: Evidence that flood control can be compatible with fisheries, wetlands, wildlife, and agriculture. Fisheries 26:6-16.

Sparks, R. E. 1995. Need for ecosystem management of large rivers and their floodplains. BioScience 45(3):168-182.

Stahle, D. W., M. K. Cleaveland, and J. G. Hehr. 1988. North Carolina climate changes reconstructed from tree rings: AD 372 to 1985. Science 240:1517-1519.

Tharme, R. E. 2003. A global perspective on environmental flow assessment: Emerging trends in the development and application of environmental flow methodologies for rivers. River Research and Applications 19:397-441.

Tockner, K. and J. A. Stanford. 2002. Riverine Flood plains: present state and future trends. Environmental Conservation 29(3):308-330. 
U.S. Army Corps of Engineers. 2000. Atchafalaya Basin Floodway System project, Louisiana master plan. U.S. Army Corps of Engineers, New Orleans District, New Orleans, LA.

van Beek, J. L., A. L. Harmon, C. L. Wax, and K. M. Wicker. 1979. Operation of the Old River control project, Atchafalaya Basin: An evaluation from a multiuse management standpoint. Contract No. 68-03-2665.

Vörösmarty, C. J., P. Green, J. Salisbury, and R. B. Lammers. 2000. Global water resources: Vulnerability from climate change and population growth. Science 289:284-288.

Water in the Basin Committee. 2002. Water in the Basin Committee Recommendations to the Governor. Atchafalaya Basin Program, Louisiana Department of Natural Resources, Baton Rouge, LA.

Watt, K. M., and S. W. Golladay. 1999. Organic matter dynamics in seasonally inundated, forested wetlands of the Gulf Coastal Plain. Wetlands 19:139-148.

Wilhite, L. P., and J. R. Toliver. 1990. Taxodium distichum (L.) Rich., Baldcypress. Pages 563572 in R. M. Burns and B. H. Honkala, editors. Silvics of North America: 1. Conifers. U.S. Department of Agriculture, Washington, DC.

Williams, B. K., R. C. Szaro, and C. D. Shapiro. 2007. Adaptive Management: The US Department of the Interior Technical Guide. Washington, DC: US Department of the Interior, Adaptive Management Working Group.

Wohl, E., P. L. Angermeier, B. Bledsoe, G. M. Kondolf, L. MacDonnell, D. M. Merritt, M. A. Palmer, N. L. Poff, and D. Tarboton. 2005. River Restoration. Water Resources Research 41(10): W10301.

Wondolleck, J. M., and S. L. Yaffee. 2000. Making Collaboration Work: Lessons from Innovation in Natural Resource Management. Island Press, Washington D.C.

Yarnell, S.M., G. E. Petts, J. C. Schmidt, A. A. Whipple, E. E. Beller, C. N. Dahm, P. Goodwin, and J. H. Viers. 2015. Functional flows in modified riverscapes: Hydrographs, habitats and opportunities. BioScience 65(10):963-972. 


\section{Figure legends}

Figure 1. The Atchafalaya River Basin, Louisiana. Also shown are the location of the basinwide flood control levees, major floodways within the Atchafalaya River Basin, the U.S. Geological Survey gages used in this study, and the spatial extent of baldcypress-water tupelo swamp forests in the Lower Atchafalaya Floodway, mapped following the Cowardin et al. (1979) National Wetlands Inventory classification system.

Figure 2: A framework for establishing environmental flows on regulated rivers within a limited decision space. Once an environmental objective is defined it is necessary to assess the hydrologic needs of the environmental objective and the current flow policy, which encompasses desired hydraulic characteristics and the current range of flow variability. The overlapping hydrologic characteristics between the flow policy and the environmental objective identify the current opportunity to prescribe environmental flows.

Figure 3: Specific-stage at Butte LaRose with a discharge of $3100 \mathrm{~m}^{3} \mathrm{~s}^{-1}(\sim 80 \%$ flow exceedance probability) at Simmesport, 1959-2012.

Figure 4: Hydrograph showing mean daily flows at Simmesport and corresponding water surface elevation (stage at Butte LaRose) for wet, average, and dry years during the study period (1988-2012). These flows and stages resulted from the current flow regime, based on the basinwide flow mandate.

Figure 5: The environmental flow prescription for the Atchafalaya River Basin, Louisiana. Shown here are the flow prescriptions for dry, average, and wet years, including the modeled flow reduction for dry years, the modeled flood pulse for average years, and the modeled small flood for wet years. Established thresholds for backswamp inundation and overbank flooding are also shown along with the upper bound of extreme low flow events as defined by IHA. 
Table 1. Environmental flow recommendations from scientific literature and reports for the Atchafalaya River Basin used to create the environmental flow prescription in this study.

\begin{tabular}{|c|c|c|}
\hline Source & Purpose & Hydrologic needs of environmental objective \\
\hline $\begin{array}{l}\text { van Beek et al. } \\
1979\end{array}$ & Habitat diversity & Minimum of 7 months of flooding for areas to be dominated by cypress-tupelo \\
\hline Bryan et al. 1998 & $\begin{array}{l}\text { Ideal watering and } \\
\text { dewatering cycle }\end{array}$ & $\begin{array}{l}\text { In Lower Atchafalaya Floodway: } 2.7 \mathrm{~m} \text { at Butte LaRose by early January, increase } \\
\text { to } 4.3 \mathrm{~m} \text { by mid-April, reduce water levels to } 1.5 \mathrm{~m} \text { by mid-June. Prolonged dry } \\
\text { periods should coincide with natural climatic drought cycles }\end{array}$ \\
\hline Sabo et al. 1999 & $\begin{array}{l}\text { Hypoxia reduction, } \\
\text { aquatic and forest } \\
\text { productivity }\end{array}$ & $\begin{array}{l}\text { Annual flood pulse should occur when temperatures are below the median. Low } \\
\text { water levels should occur during high temperatures, prolonged low water levels } \\
\text { beneficial to aquatic and forest productivity }\end{array}$ \\
\hline $\begin{array}{l}\text { Water in the } \\
\text { Basin Committee } \\
2002\end{array}$ & $\begin{array}{l}\text { Water quantity and } \\
\text { quality; } \\
\text { socioeconomics }\end{array}$ & $\begin{array}{l}\text { Water begins to flow into backswamp areas at } 2.7 \mathrm{~m} \text {, good overbank flow at } 5.2 \mathrm{~m} \text {. } \\
\text { Introduce additional flow January-April if water temperatures are below } 20^{\circ} \mathrm{C} \text {, avoid } \\
\text { additional flow May-December }\end{array}$ \\
\hline Keim et al. 2006 & $\begin{array}{l}\text { Cypress-tupelo } \\
\text { forest productivity } \\
\text { and regeneration }\end{array}$ & $\begin{array}{l}\text { Low-water events, } \approx 0.6 \mathrm{~m} \text { at Butte LaRose, required to maximize cypress-tupelo } \\
\text { regeneration potential. Widespread artificial planting possible at } \approx 1.6 \mathrm{~m} \text { at Butte } \\
\text { LaRose }\end{array}$ \\
\hline Hupp et al. 2008 & $\begin{array}{l}\text { Sedimentation and } \\
\text { inundation patterns }\end{array}$ & $\begin{array}{l}\text { Study sites in Lower Atchafalaya Floodway experienced flooding in backswamp } \\
\text { areas at } 2.8 \mathrm{~m} \text { at Butte LaRose and banks were overtopped around } 3.7 \mathrm{~m}\end{array}$ \\
\hline $\begin{array}{l}\text { Faulkner et al. } \\
2009\end{array}$ & $\begin{array}{l}\text { Cypress tupelo } \\
\text { natural regeneration } \\
\text { potential }\end{array}$ & $\begin{array}{l}\text { Prolonged extreme low-flows ( } 0.5 \mathrm{~m} \text { at Butte LaRose) maximize natural and artificial } \\
\text { regeneration potential of cypress-tupelo forests }\end{array}$ \\
\hline $\begin{array}{l}\text { Louisiana } \\
\text { Crawfish } \\
\text { Promotion and } \\
\text { Research Board } \\
2009\end{array}$ & $\begin{array}{l}\text { Socioeconomics, } \\
\text { crawfish harvest } \\
\text { and production }\end{array}$ & $\begin{array}{l}\text { Water begins to flow into backswamp areas at } 2.7 \mathrm{~m} \text { at Butte LaRose, good } \\
\text { overbank flow at } 5.2 \mathrm{~m} \text {. Crawfish benefit from } 2 \text { month summer drought and } \\
\text { floodwaters in mid-winter }\end{array}$ \\
\hline $\begin{array}{l}\text { Alford and } \\
\text { Walker } 2013\end{array}$ & $\begin{array}{l}\text { Fisheries } \\
\text { production }\end{array}$ & $\begin{array}{l}3.6 \mathrm{~m} \text { flood stage at Butte LaRose beneficial for fisheries production, } 6.1 \mathrm{~m} \text { flushes } \\
\text { hypoxic water and sediment in some areas, deposits sediments and nutrients in } \\
\text { others. Fisheries production optimized with approximate stage of } 4.0 \mathrm{~m} \text { for } 4-5 \\
\text { months during winter-spring months }\end{array}$ \\
\hline
\end{tabular}


Table 2: The environmental flow prescription for the Atchafalaya River Basin, Louisiana. Shown here are the individual flow targets of the prescription, including minimum flood season flows, maximum dry season flows, high-flow pulses, small floods, and flow reductions.

\begin{tabular}{|c|c|c|c|c|c|}
\hline Flow Targets & $\begin{array}{l}\text { Water Year } \\
\text { Classification }\end{array}$ & Timing/Duration & $\begin{array}{c}\text { Stage } \\
\text { at } \\
\text { BLR } \\
(\mathrm{m})\end{array}$ & $\begin{array}{c}\text { Approximate } \\
\text { Discharge at } \\
\text { Simmesport } \\
\left(\mathrm{m}^{3} \mathrm{~s}^{-1}\right)\end{array}$ & $\begin{array}{c}\text { IHA } \\
\text { Environmental } \\
\text { Flow } \\
\text { Component }\end{array}$ \\
\hline \multicolumn{6}{|l|}{ Flood Season } \\
\hline Early January minimum flow & All & By January 5 & 2.7 & 6340 & Low flow \\
\hline Mid-April minimum flow & All & By April 15 & 4.3 & 9850 & High flow \\
\hline May 15 minimum flow & Average & Through May 15 & 4.3 & 9850 & High flow \\
\hline June 1 minimum flow & Wet & Through June 1 & 4.3 & 9850 & High flow \\
\hline \multicolumn{6}{|l|}{ Dry Season } \\
\hline Maximum flow & Dry, average & $\begin{array}{r}\text { June 15-October } \\
15\end{array}$ & 1.5 & 4020 & Low flow \\
\hline Maximum flow & Wet & $\begin{array}{r}\text { July 1-October } \\
15\end{array}$ & 1.5 & 4020 & Low flow \\
\hline \multicolumn{6}{|l|}{ Pulses, Floods, Reductions } \\
\hline Spring high flow & Average & $\begin{array}{r}22 \text { days between } \\
\text { March } 15 \text { and } \\
\text { May } 15 \\
67 \text { davs between }\end{array}$ & 5.2 & 12300 & High flow pulse \\
\hline Small flood & Wet & $\begin{array}{r}\text { March } 15 \text { and } \\
\text { May } 31\end{array}$ & 6.1 & 17300 & Small flood \\
\hline Flow reduction & Dry & $\begin{array}{r}\text { July } 1 \text { - October } \\
31\end{array}$ & 0.7 & 1930 & Extreme low flow \\
\hline
\end{tabular}


Table 3: Annual, seasonal, and quarterly breakdown of recorded flow volumes relative to prescribed flows. The percent deviation in flow is the deviation of recorded flows from the flow prescription. Shaded cells represent recorded flow volumes that were able to meet both the flow prescription and the 70/30 flow mandate, including the $+/-7.5 \%$ operational margin, for the given time period. Flood season (minimum flow requirements): dry years $=$ January 5 to April 15; average years $=$ January 15 to May 15 ; wet years $=$ January 15 to June 1 . Dry season (maximum allowed flows): dry years $=$ June 15 to October 31 ; average years $=$ June 15 to October 15; wet years $=$ July 1 to October $15 .{ }^{*}$ Counted as part of the dry season.

\begin{tabular}{lll|r|r|rrrr}
\hline \multirow{2}{*}{ Year } & Classification & & \multicolumn{9}{c}{$\begin{array}{c}\text { Percent } \\
\text { Deviation }\end{array}$} \\
& & Annual & $\begin{array}{c}\text { Flood } \\
\text { Season }\end{array}$ & $\begin{array}{c}\text { Dry } \\
\text { Season }\end{array}$ & $\begin{array}{c}\text { Jan- } \\
\text { March }\end{array}$ & $\begin{array}{c}\text { April- } \\
\text { June }\end{array}$ & $\begin{array}{c}\text { July- } \\
\text { Sept }\end{array}$ & $\begin{array}{r}\text { Oct- } \\
\text { Dec }\end{array}$ \\
\hline 1988 & Dry & -9 & 6 & -29 & 13 & -39 & -27 & -12 \\
1989 & Average & 11 & 12 & 29 & 23 & 8 & 25 & -39 \\
1990 & Average & 17 & 9 & 30 & 16 & 22 & 19 & -15 \\
1991 & Wet & 9 & 13 & -26 & 34 & -5 & -21 & 5 \\
1992 & Average & -9 & -28 & 15 & -11 & -98 & 15 & 8 \\
1993 & Wet & 24 & 8 & 51 & 20 & 4 & 51 & 34 \\
1994 & Average & 8 & 16 & -9 & 16 & 42 & -9 & -16 \\
1995 & Average & 0 & -25 & 32 & -14 & -2 & 22 & -49 \\
1996 & Average & 9 & -27 & 27 & -28 & 2 & 13 & 26 \\
1997 & Average & 15 & 25 & 17 & 29 & 9 & 6 & -54 \\
1998 & Wet & 2 & 1 & 18 & 17 & -14 & 23 & -12 \\
1999 & Average & -3 & 7 & 1 & 18 & -29 & -2 & -16 \\
2000 & Dry & -21 & -82 & 43 & -100 & -18 & 49 & -12 \\
2001 & Average & -3 & -10 & 0 & 3 & -11 & -12 & 4 \\
2002 & Average & 4 & -1 & -6 & -5 & 31 & -27 & -13 \\
2003 & Average & -4 & -27 & 15 & -5 & -40 & 10 & -16 \\
2004 & Average & 12 & -13 & 31 & 1 & 2 & 23 & 31 \\
2005 & Dry & 8 & 17 & 31 & 23 & -14 & 34 & -38 \\
2006 & Dry & -17 & -60 & 26 & -57 & -36 & 19 & 26 \\
2007 & Dry & 11 & -4 & 48 & -1 & 1 & 56 & -1 \\
2008 & Wet & 8 & 4 & 35 & 2 & 11 & 37 & -36 \\
2009 & Wet & 9 & -23 & 19 & -17 & -6 & 16 & 44 \\
2010 & Average & 12 & 5 & 29 & 12 & 12 & 29 & -36 \\
2011 & Wet & 4 & -13 & 19 & -35 & 13 & 23 & 7 \\
2012 & Dry & -16 & -2 & -1 & 2 & -38 & 0 & -46 \\
\hline & & 7 & 15 & 7 & 18 & 15 & 8 & 19 \\
\hline
\end{tabular}


Table 4: Monthly breakdown of recorded flow volumes relative to prescribed flows. The percent deviation in flow is the deviation of recorded flow volumes from prescribed flow volumes. Shaded cells represent recorded flow volumes that were able to meet both the flow prescription and the 70/30 flow mandate, including the $+/-7.5 \%$ operational margin, for the given time period. June, November, and December are transition period months and not subject to maximum or minimum flows for the flow prescription, therefore they were only evaluated for adherence to the flow mandate.

\begin{tabular}{|c|c|c|c|c|c|c|c|c|c|c|c|c|c|}
\hline \multirow{2}{*}{ Year } & \multirow{2}{*}{ Classification } & \multicolumn{12}{|c|}{ Percent Deviation } \\
\hline & & Jan & Feb & March & April & May & June & July & Aug & Sept & Oct & Nov & Dec \\
\hline 1988 & Dry & 32 & 16 & -16 & -13 & -70 & -80 & -30 & -25 & -25 & -10 & -15 & -11 \\
\hline 1989 & Average & 23 & 10 & 32 & 2 & -24 & 44 & 53 & -13 & -1 & -4 & -38 & -85 \\
\hline 1990 & Average & -30 & 27 & 27 & -8 & 14 & 65 & 42 & 7 & -3 & -12 & -33 & -5 \\
\hline 1991 & Wet & 54 & 24 & 15 & -30 & -4 & 24 & 12 & -42 & -60 & -86 & -8 & 35 \\
\hline 1992 & Average & 11 & -47 & -11 & -59 & -63 & 5 & 16 & 32 & -15 & -26 & -17 & 23 \\
\hline 1993 & Wet & 35 & 7 & 14 & -10 & 4 & 23 & 51 & 59 & 39 & 42 & 18 & 37 \\
\hline 1994 & Average & -13 & 21 & 27 & 9 & 27 & 10 & 15 & -16 & -43 & -44 & -28 & 5 \\
\hline 1995 & Average & -17 & -16 & -9 & -70 & 2 & 65 & 47 & 15 & -36 & -46 & -35 & -65 \\
\hline 1996 & Average & -50 & -3 & -38 & -39 & 1 & 60 & 31 & 16 & -22 & -4 & 20 & 41 \\
\hline 1997 & Average & 12 & 21 & 42 & 24 & 2 & 49 & 38 & -14 & -45 & -53 & -58 & -51 \\
\hline 1998 & Wet & 26 & 12 & 14 & -31 & -10 & 4 & 51 & 16 & -47 & -9 & -8 & -19 \\
\hline 1999 & Average & -4 & 40 & 7 & -29 & 8 & 32 & 35 & -17 & -87 & -3 & -156 & -99 \\
\hline 2000 & Dry & -145 & -207 & -41 & -31 & -45 & 25 & 68 & 38 & 13 & 14 & -4 & -32 \\
\hline 2001 & Average & -36 & -7 & 25 & -29 & -45 & 42 & 15 & -19 & -49 & -26 & -52 & 35 \\
\hline 2002 & Average & -2 & 12 & -29 & 11 & 18 & 52 & -2 & -40 & -49 & -6 & -14 & -17 \\
\hline 2003 & Average & -3 & -55 & 16 & -82 & -6 & 47 & 25 & 6 & -7 & -34 & -39 & 6 \\
\hline 2004 & Average & 5 & 5 & -4 & -55 & -20 & 50 & 48 & -4 & 2 & 0 & 23 & 47 \\
\hline 2005 & Dry & 41 & 32 & -13 & -17 & -31 & 13 & 46 & 15 & 35 & 18 & -31 & -93 \\
\hline 2006 & Dry & -90 & -29 & -65 & -80 & -17 & -5 & 30 & 10 & 15 & 48 & 41 & -5 \\
\hline 2007 & Dry & 27 & -10 & -29 & -21 & 9 & 21 & 67 & 47 & 46 & 20 & 0 & -14 \\
\hline 2008 & Wet & -15 & -7 & 14 & 11 & 0 & 28 & 53 & 20 & 28 & -2 & -77 & -43 \\
\hline 2009 & Wet & 6 & -35 & -27 & -60 & -6 & 37 & 29 & 16 & -3 & 46 & 54 & 32 \\
\hline 2010 & Average & 22 & 33 & -6 & -12 & 2 & 44 & 44 & 29 & -2 & -10 & -63 & -39 \\
\hline 2011 & Wet & 14 & -109 & 9 & -43 & 22 & 45 & 46 & 13 & -9 & -39 & -37 & 38 \\
\hline 2012 & Dry & 11 & 12 & -17 & -36 & -41 & -37 & 9 & -7 & -3 & 6 & -36 & -93 \\
\hline & Totals & 17 & 17 & 14 & 5 & 15 & 3 & 2 & 12 & 19 & 19 & 3 & 4 \\
\hline
\end{tabular}




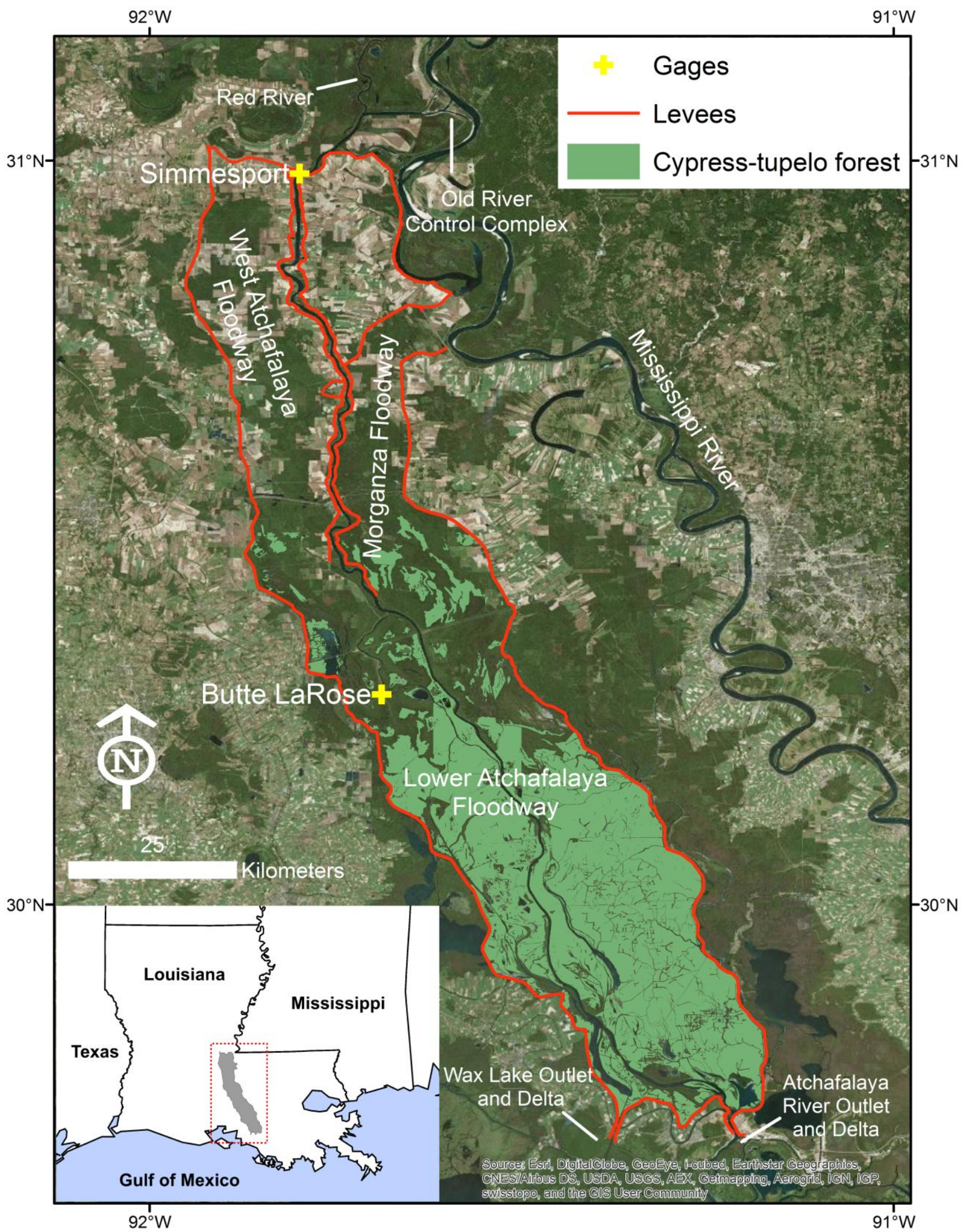

Figure 1 


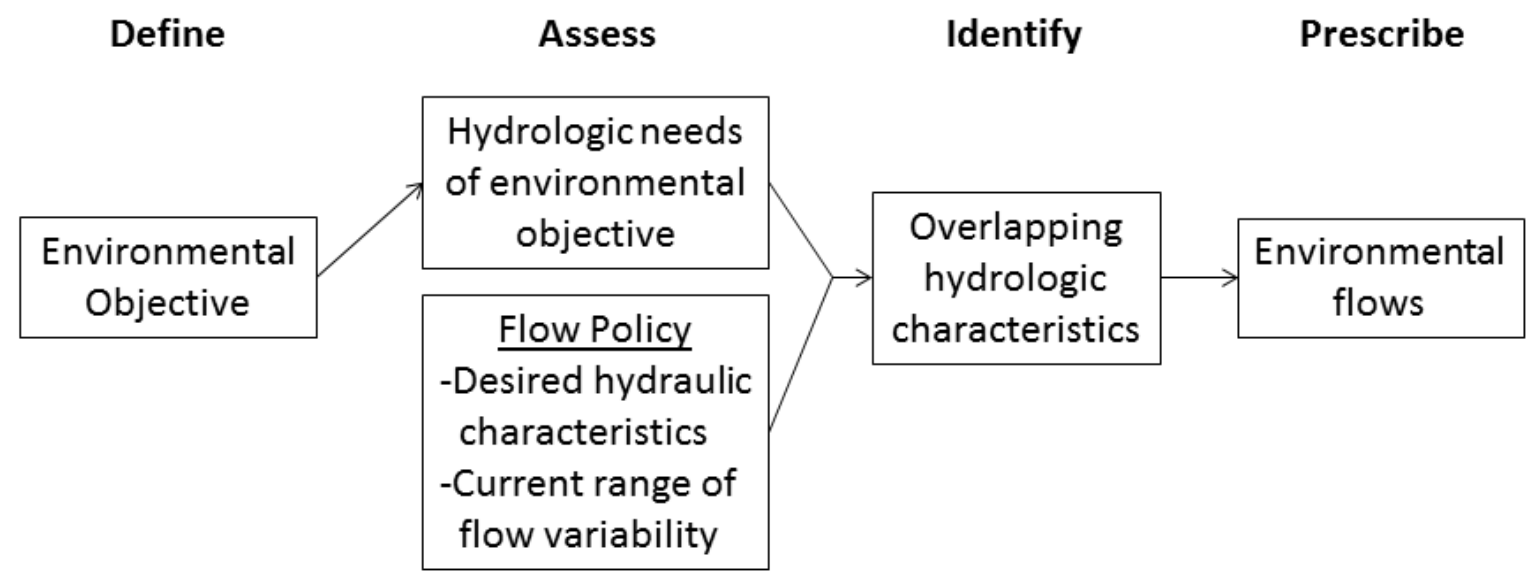

Figure 2 


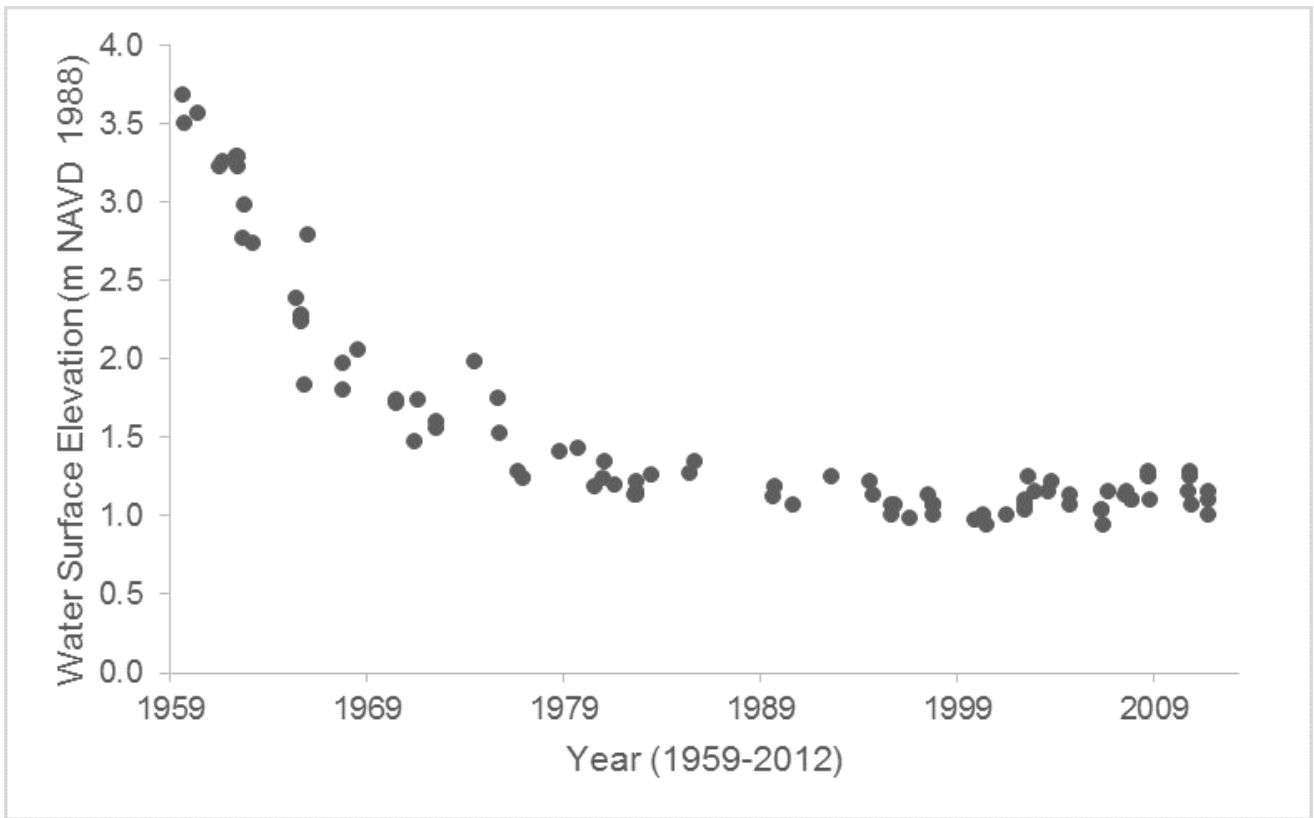

Figure 3 


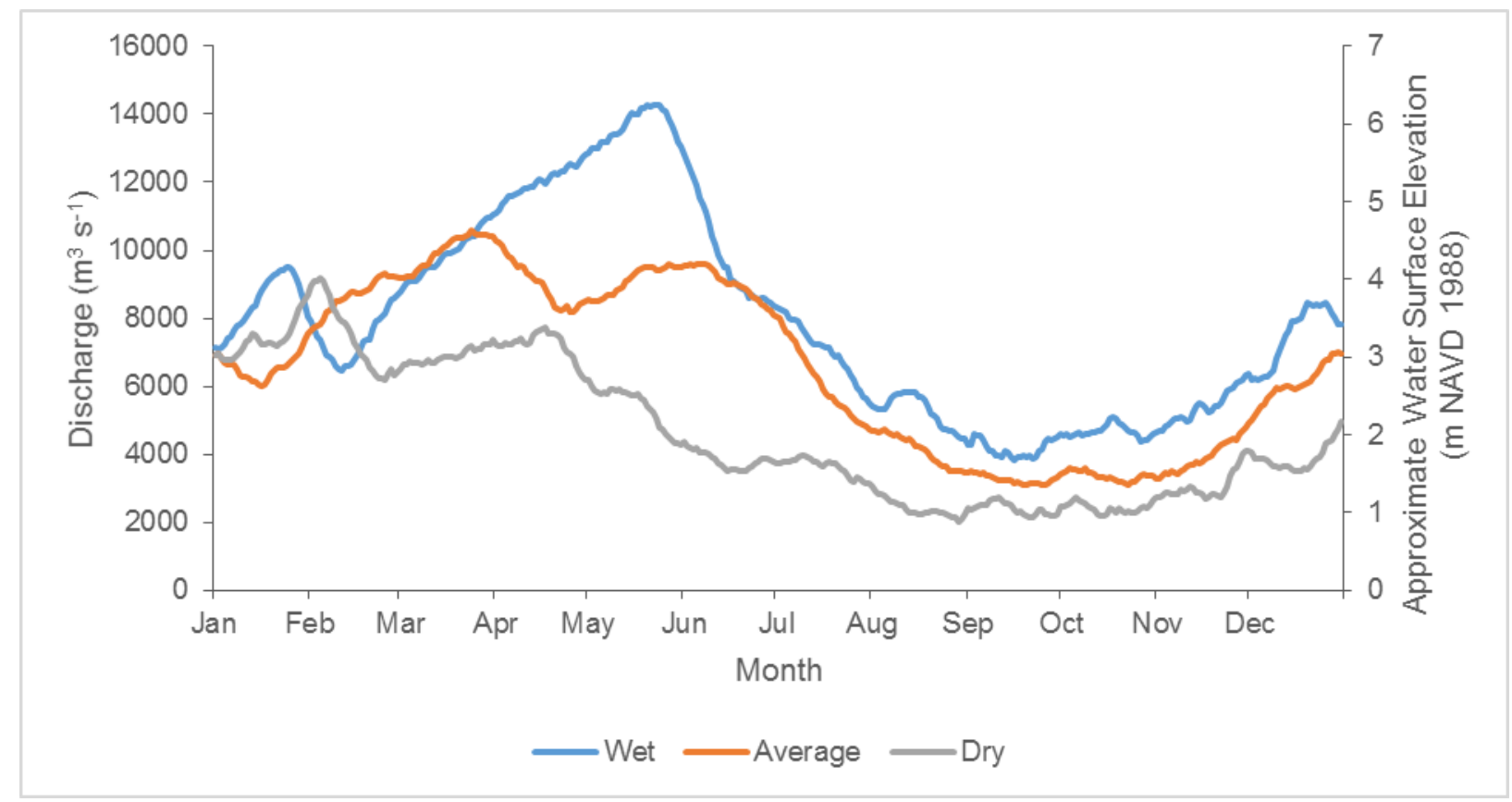

Figure 4 


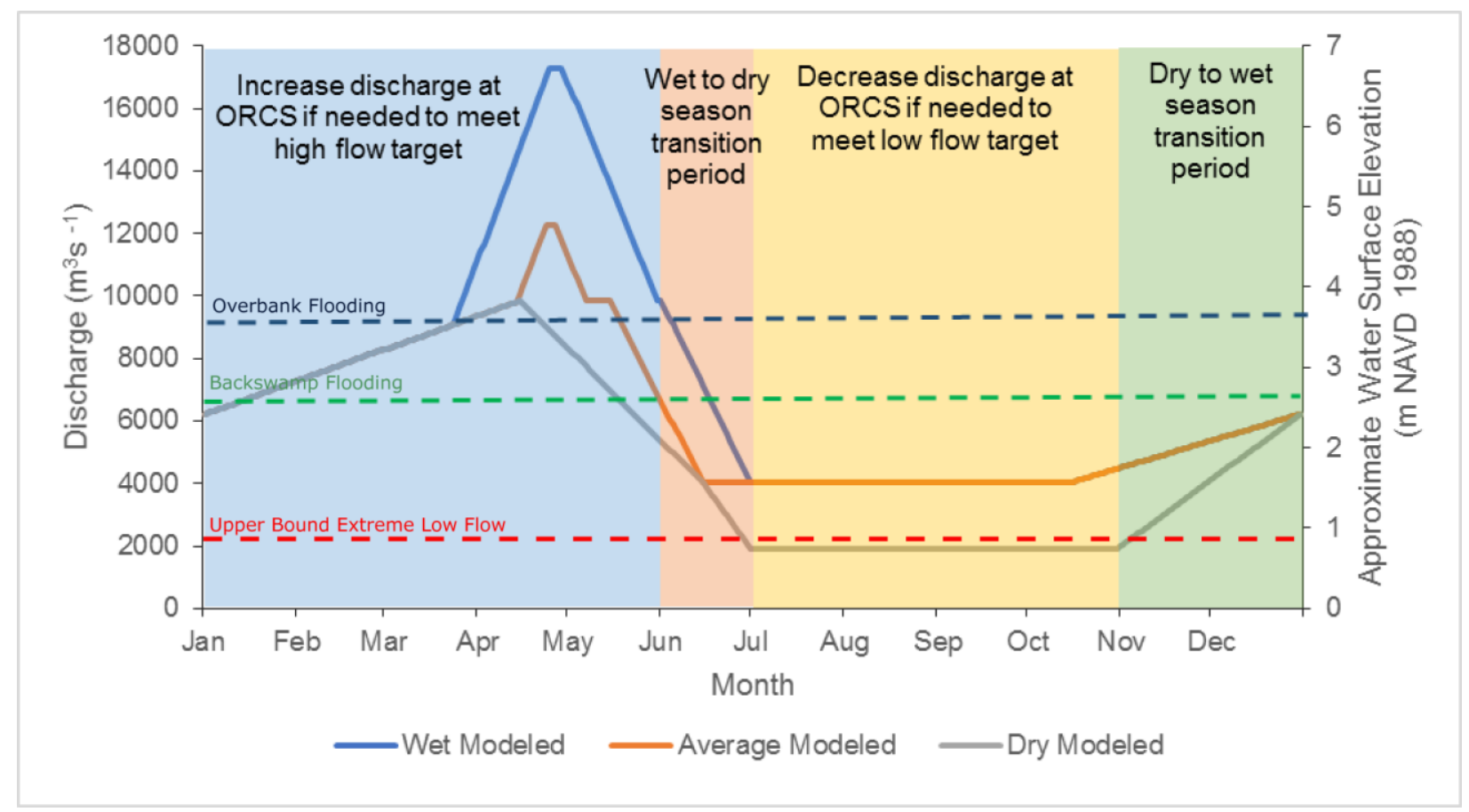

Figure 5 